\title{
The Legal Framework of Faculty Collective Bargaining: Some Short Questions and Some Long Answers*
}

\author{
BERNARD ADELL**
}

1. Are faculty associations too "employer influenced" to be eligible for certification as bargaining agents?

When it applies for certification, a faculty union has to satisfy the provincial labour relations board on at least three counts. First, it must be a "trade union." In the words of the Nova Scotia Trade Union Act, which reflect the law across Canada, this merely means that it must have "a constitution and rules or by-laws setting forth its objects and purposes" and defining its membership requirements, and that those objects must "include regulating relations between employers and employees."1 Second, once it has established its status as a trade union, it must prove that it has majority support in the unit of employees it seeks to represent. $^{2}$ Third, and again in the terms of the Nova Scotia statute, which are relatively precise and relatively liberal on this matter, its "administration, management, or policy "must not be dominated or influenced by an employer, so that its fitness to represent employees for the purpose of collective bargaining is impaired ..."3 In other words, because collective bargaining is deemed to be an adversary process, the union must be in a position to be a true adversary of the employer.

Canadian labour relations boards are quite stringent in their application of the requirement that a trade union be free of employer influence - stringent enough to raise potential problems for a faculty association accustomed to a fairly close and comfortable relationship with the university administration. It will not suffice for the association to argue that its heart is pure and that its officers and active supporters are subjectively free of any subservience. What is required is the absence of objective evidence from which a labour relations board, properly wary of the perennial attempts of employers in industry and commerce to encourage docile

*This paper was presented to The University and the Law Conference, Dalhousie University, March 1, 1975

**Professor, Faculty of Law, Queen's University.

${ }^{1}$ Statutes of Nova Scotia 1972 , c. 19, s. 1(1) (w).

${ }^{2}$ Sections 22(1), 24(1)-(5)

${ }^{3}$ Section $24(7)$ 
unions, might reasonably infer that the association is something less than totally independent of the university administration.

The objective evidence which most commonly leads to a finding of employer influence is of two sorts. First is the presence in the union of any significant number of persons who exercise "management" functions and who are therefore ineligible in law for inclusion in the bargaining unit. Later I will say a bit more about who exercises management functions in the faculty context. Here I will merely point out that presidents, vice-presidents and deans, many of whom commonly remain members of faculty associations after obtaining their administrative positions, are quite clearly management personnel and that their membership in a faculty association at the time of a certification application may well result in the dismissal of that application, at least in Ontario and perhaps elsewhere. All that the Ontario Labour Relations Board requires as the basis for such a dismissai is "a potential for a conflict of interest with respect to certain issues in collective bargaining." 4 The fact that neither side ever considered the tainted employees in question to be members of management does not appear to make any difference. ${ }^{5}$

The second sort of fact which evidences employer influence is the provision of any support by the employer to the union during (or preceding) its organizing campaign. A request by the employer that an employee join the union is obviously objectionable, as is the giving of direct financial handouts to the union. More subtle and troublesome in the university context are the various little services which the faculty association may over the years have persuaded the university to perform for it. One such service which might be taken as evidence of employer influence, if past decisions of the Ontario Labour Relations Board are any guide, is the deduction of faculty association dues from members' pay, ${ }^{6}$ whether under an opting-out or even an opting-in arrangement.

Although labour relations boards in some provinces may well take cognizance of the particular nature of relationships within a university and refuse to find employer influence from facts of the sort just mentioned, it is dangerous to predict such a result in any specific case. Faculty association members at St. Mary's, and more recently at Carleton University, were wise in deciding to constitute an entirely new faculty union having no direct ties with the old association before making application for certification.

\section{Might a university administration inadvertently give a faculty association full statutory collective bargaining rights by negotiating a few matters with it?}

In every province except Quebec, an employer can confer statutory bargaining rights upon a trade union by voluntarily recognizing it as bargaining agent for his employees. Unless the union is employer-influenced (which is not uncommonly the case with voluntarily recognized unions in industry and commerce), a written collective agreement following upon such recognition gives it substantially the same bargaining rights, and nearly as much protection

${ }^{4}$ Hydro-Electric Power Commission of Ontario [1971] JOLRB Rep. (Aug.) 501, at p. 504

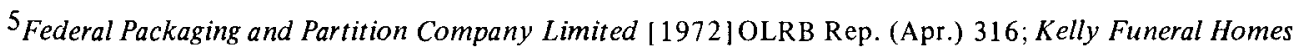
Limited [1973] OLRB Rep. (Feb.) 87

${ }^{6}$ Scott Haulage Limited [1962-63 ] OLRB Rep. (Mar.) 422 
against displacement by rival unions, as it would receive from a collective agreement made after the granting of certification by the labour relations board. ${ }^{7}$

In some provinces, the statutory definition of "collective agreement" or "collective bargaining" is so broad that a university administration which makes any written agreement with a faculty association covering even a few of the employment terms of faculty members may discover later that it has inadvertently conferred statutory bargaining rights on that association and has thereby precluded itself from negotiating any terms and conditions of employment with any other organization of faculty members (such as a group of law teachers or engineering teachers) or even with individual faculty members. As I have tried to show elsewhere, ${ }^{8}$ this may be the situation in Alberta, and it may also be the case in Ontario, ${ }^{9}$ New Brunswick ${ }^{10}$ and other provinces. In Nova Scotia, however, the Trade Union Act is rather more strict. The relevant provisions are not entirely clear, but they appear to say that an agreement made with an uncertified union does not confer statutory bargaining rights unless it contains some language to the effect that "the employer recognizes the trade union as the exclusive bargaining agent for the employees" and some language defining "the unit of employees to which the agreement extends ..."11 A faculty association, then, can acquire bargaining rights through voluntary recognition by the university administration in Nova Scotia as elsewhere, but the inadvertent conferral of such rights seems to be precluded in that province.

\section{Will groups other than the "core faculty" be covered by faculty collective bargaining?}

When a union applies for certification, it must specify the "unit" of employees for which it seeks bargaining rights. The labour relations board has the statutory duty of determining whether the unit applied for is one "appropriate" for collective bargaining. The general criterion used by Canadian boards, and made obligatory in Nova Scotia by s. 24(6) of the Trade Union Act, is that of "community of interest among the employees in the proposed unit in such matters as work location, hours of work, working conditions and methods of remuneration."

The question whether part-time faculty members or professional librarians will be included in a university-wide bargaining unit is not capable of any general answer. The American National Labor Relations Board, after including part-timers in some cases, has more recently excluded them because (among other things) their obligation to the university is much more

${ }^{7}$ Statutory provisions such as s. 52 of the Ontario Labour Relations Act, RSO 1970, c. 232, do make it somewhat easier to displace a voluntarily recognized union than a certified one.

${ }^{8}$ See my "Collective Bargaining Rights for Facuity at the University of Alberta," published in 1974 by the Association of the Academic Staff of the University of Alberta, pp. 74-78.

${ }^{9}$ Ontario Labour Relations Act, ss. 1(1) (e), 5(4)

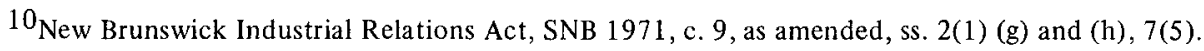

${ }^{11}$ Nova Scotia Trade Union Act, ss. 1(1) (e) and (f), 28(1) and (2). Section 28(2) also makes the filing of the agreement with the Minister a prerequisite to its conferring of bargaining rights, but it appears from s. 44 (thought again not very clearly) that the filing of the agreement by one party would suffice for this purpose. 
confined than that of full-time faculty to the teaching of courses and does not commonly include research, student counselling, or administration. ${ }^{12}$ Another American board had previously held that part-timers should be excluded because, for many of them, their "primary professional commitments are elsewhere." 13 In English-speaking Canada, they have been included at Notre Dame University but excluded elsewhere, with no written reasons given for any decision. If the considerations relied on in the United States can be taken as any sort of guide, it may be possible to distinguish those part-timers who teach only one course and have full-time duties elsewhere from those who teach more than one course, participate in the affairs of their department, and have no other employment. The latter, thought usually few in number, have a close community of interest with their full-time colleagues. The former may indeed be seen by some university administrations as a cheap and flexible substitute for additional full-timers, and their inclusion in the unit might lessen the temptation to use large numbers of them. Their exclusion could, however, bring about the same result if it were followed by a provision in the collective agreement restricting their use.

Professional librarians too are included at some places but not at others. At Manitoba and Notre Dame they are in. At St. Mary's they are out, but the same faculty union that is certified for the faculty-wide unit is now certified for them as a separate unit. In New York University, the NLRB included them, despite the many differences in their work patterns and terms of employment, for the reason that they were "a closely allied professional group" which shared in and aided the achievement of the university's educational and scholarly goals. $^{14}$

Another important problem in bargaining unit determination - and a particularly difficult one with regard to university faculty - is that of determining who is to be excluded from the unit because he "exercised management functions." At one extreme, it is sometimes suggested that all faculty members are "managerial" because of their participation in university governance through senates, department councils, commit tees and the like. No North American labour relations board has ever accepted this argument, and it no longer has any chance of success. ${ }^{15}$

Most Canadian labour relations statutes do not contain a comprehensive definition of who is an "employee' for the purpose of inclusion in the bargaining unit, but merely provide for some sort of exclusion of management personnel and persons exercising "confidential" functions relating to the employer's labour relations. In general, presidents, vice-presidents, registrars, chief librarians, and a few assorted assistants have been excluded from faculty units in the United States and Canada, but department chairmen and associate deans are now

${ }^{12}$ New York University (1973) 83 LRRM 1549, at 1552-53; prohibitory injunction denied, (1973) 364 F. Supp. 160 (SDNY)

${ }^{13}$ City University of New York (1968) 2 PERB Cas. 3000 (N.Y. Pub. Emp. Rel. Bd.) quoted by Kahn, "The NLRB and Higher Education: the Failure of Policymaking through Adjudication," (1973) 21 UCLA L. Rev. 63, at pp. 112-13.

14(1973) 83 LRRM 1549, at p. 1553.

${ }^{15}$ For a closely reasoned analysis of the issue, see the decision of the Labour Relations Board of British Columbia in Vancouver City College (Langara) [1974] 1 Canadian LRBR 298. 
generally included as being predominantly non-managerial. ${ }^{16}$ Faculty members who sit on the university's board of governors are also generally excluded. In the St. Mary's University case, ${ }^{17}$ where the Nova Scotia Labour Relations Board had the task of applying to university faculty the Trade Union Act's unusual inclusive definition of an "employee" as "a person employed to do skilled or unskilled manual, clerical or tehnical work," the Board's holding in favour of employee status of faculty members was based, I am told, on the words "skilled ... technical work." Labour relations boards in other provinces do not have the task of fitting faculty members into the uncomfortable mould of an inclusive definition of that sort.

In setting bargaining unit boundaries, labour relations boards will give some weight to any agreement which the parties may have reached on who should be included or excluded, subject to the requirements of the statute and to policies previously developed by the particular board. ${ }^{18}$ This enables the administration and the faculty union to make a joint attempt to shape the bargaining unit in accordance with the needs of their own university.

4. Under a regime of collective bargaining, what can be done to preserve salary differentials for faculty members with highly marketable skills?

The general answer to this question is, "Pretty well any thing the parties want to do." Two more specific questions then have to be asked. Will the parties be able to meet the difficulties involved in devising a procedure that will preserve necessary market differentials? And will Canadian labour relations boards have the good sense to look beyond those difficulties and to certify faculty bargaining agents on a university-wide rather than a faculty-by-faculty basis?

The only English-language university in Canada with a full range of "professional" faculties and a certified faculty bargaining agent is the University of Manitoba. The Manitoba Labour Relations Act has the unique provision that "the Board shall not include professional employees in a unit with employees who are not professional employees unless it is satisfied that a majority of the professional employees wish to be included in the unit."19 Late in 1974, the University of Manitoba's "professional" faculty members, voting as one group, narrowly chose to stay out of the university-wide unit. In the United States, the NLRB has recently allowed some law faculties to opt out of such units, ${ }^{20}$ and it is all too likely that Canadian law faculties, if given the chance, would also opt out.

Such fragmentation of the university-wide unit would, I am convinced, be unfortunate for everyone involved. The community of interest between any academically sound profes-

161 have dealt with the management exclusion at some length in "Establishment of Faculty Collective Bargaining: the Developing Law," to appear in Proceedings of Conference on Universities and the Law, University of Manitoba, 1974.

17 Nova Scotia LRB No. 2056, as amended, April 25, 1974.

${ }^{18}$ Sack and Levinson, Ontario Labour Relations Board Practice, Butterworths, Toronto, 1973, at pp. $57-58$.

19CCSM, c. L10 (enacted 1972), s. 29(3). "Professional employee" is defined in s. 1(t).

${ }^{20}$ See, for example, Syracuse University (1973) 83 LRRM 1373. 
sional faculty and the rest of the university is very strong on every matter except salaries and perhaps promotions, and even the pressing current need of professional faculties to pay substantially more money and promote more quickly in order to attract and keep competent staff may not exist forever. Yet the strength of that need, at least for the foreseeable future, is unquestionable if such disciplines as law are to be taught by people of roughly the same calibre as those who teach in fields where the outside demand for their services is much less intense. This is an unpleasant reality of the labour market which may be distasteful to anyone who looks upon marketbased salary differentials as unjust but which must be taken fully into account as long as our society allows self-employed professionals to charge what the traffic will bear.

Two legal realities must also be noted. First, in provinces other than Manitoba, there is no need for labour relations boards to allow professional faculties to opt out of universitywide units. In fact, in Quebec, where the relevant section of the Labour Code has clear similarities to that of the Manitoba Act, the Labour Court has firmly refused to allow such opting out. ${ }^{21}$ Second, there are no legal obstacles to the inclusion in a collective agreement of any one of a wide variety of arrangements that might permit adequate market differentials while preventing them from becoming unreasonably large. One such arrangement would have the union and the administration negotiate separate salary scales for highly marketable groups. Due to pressures toward equalization that seem to exist within most faculty unions, this would probably provide inadequate differentials. At the other extreme, the parties to the collective agreement could agree that its salary scales were to be minima only, and that any faculty member could make an individual arrangement with the university for higher pay. The general unacceptability of such arrangements under a regime of collective bargaining is quite obvious. The proposal I find the most promising is one which would, by agreement between the employer and the faculty union, remove the question of differentials from the bargaining table altogether and put it in the hands of a specialized body consisting of representatives from the board of governors, the senate and the union. That body would hear representations from any group or individual that wished to be heard, and would then draw up a scale of differentials that would be mandatorily applied to the basic salary scale negotiated at the bargaining table. In effect, the parties to collective bargaining would delegate the function of setting market differentials to another forum better situated to perform it, and would bind themselves to abide by the results reached in that forum. ${ }^{22}$

\section{What will happen to merit pay and other means of recognizing excellence?}

In law, the answer to this question is the same as the anser to the last one: the parties to collective bargaining can agree to recognize merit in almost any way they want.

But will faculty collective agreements leave as much leeway for merit pay, merit promotions and the like as now exists in Canadian universities? This question is difficult even to approach without some knowledge of how much tangible recognition merit now receives. How many faculty members are now given significant extra pay because of their performance as teachers or researchers? How much of what passes for merit pay is really a market differential

${ }^{21}$ Quebec Labour Code, RSQ 1964, c. 141, as amended, s. 20. See, for example, Université Laval v. Association des Ingénieurs Professeurs de la Faculté des Sciences [1971] T. T. 281.

${ }^{22}$ This idea comes from Richard Spencer, President of the Canadian Association of University Teachers. 
unrelated to the individual's own merit? How much of it is really due to the fact that he had the good fortune to be around, and at an early stage in his career, during the sellers' market of the middle to late sixties? How often is it due to the fact that there were one or two highly meritorious people at his level, and that he was moved along with them to avoid hard feelings? How often are available merit moneys now spread evenly or almost evenly among all members of a department because no one has much confidence in the merit evaluation procedures? How many truly meritorious faculty members expect, appreciate and respond beneficially to any merit pay that they may receive?

It is possible that the answers to these questions would show that merit pay means something in Canadian universities. And it is true that the first two university faculty collective agreements in English-speaking Canada, at Notre Dame and St. Mary's, make no reference to such pay. However, both of those agreements (particularly that at Notre Dame) make extensive attempts to improve evaluation criteria and machinery in order that appointment, promotion and tenure decisions be based on a thorough evaluation of the various aspects of the individual's performance. Given the present state of merit evaluation in most if not all Canadian universities, such attempts to articulate criteria and strengthen procedures may be expected to have beneficial effects.

\section{Can faculty collective bargaining do much for job security?}

No single issue, in my view, will be more important in faculty collective bargaining over the next few years than job security. Facuty members in subject areas that are the most susceptible to cutbacks are often in a poor position to find other employment well suited to their backgrounds, and there is no compelling reason, legal or otherwise, for leaving academic retrenchment decisions wholly in the hands of the administration.

Here again, as with the preceding questions, the keynote of the legal position is flexibility. If the parties to collective bargaining agree that limitations should be placed on the university's right to reduce course offerings and other academic services and on its right to lay off faculty members, such limitations will in all likelihood be fully enforceable through the grievance and arbitration provisions of the collective agreement. The only significant reservation may involve the powers over academic programs given to senates and other shared-authority bodies by some university statutes. However, such statutes, depending on their specific wording, are more likely to place additional obstacles in the way of the projected retrenchment than to make it a non-bargainable issue.

The question of protection against loss of employment through employer reduction in the scope of operations has long been a bargainable issue in industry, but collective bargaining has not generally brought such protection in any remarkable degree. Most industrial collective agreements still do little more than provide that junior employees will be laid off first, and perhaps provide a temporary financial cushion for those who do lose their jobs. Employers have been understandably reluctant to sign away their common law right to lay off or terminate anyone whose services are no longer needed, and arbitrators have not found employers to have implicitly surrendered that right by merely embarking upon collective bargaining or entering into an ordinary collective agreement. ${ }^{23}$ Complete protection against job loss through

${ }^{23}$ See generally Weiler, Labour Arbitration and Industrial Change, Information Canada, Ottawa, 1969. 
employer retrenchment is commonly felt to be too big a problem to be capable of solution by collective bargaining, especially if the retrenchment is caused by labour-saving technological changes. In the Canadian university context, this feeling is strengthened by an almost complete financial dependence on government and by the expectation that no government which was determined to make drastic cuts in grants to higher education would be deterred by the fact that a faculty collective agreement purported to guarantee absolute job security.

Still, there is an increasing acceptance across Canada that no eternal principle of justice underlies the tendency of many employers to make employee layoffs their first and foremost move whenever they feel the need to retrench. The Canada Labour Code, for example, imposes an obligation on employers in the federal jurisdiction to bargain with their employees' bargaining agent in certain technological change situations, even if a collective agreement is already in effect. ${ }^{24}$ The British Columbia Labour Code requires every collective agreement to provide for the arbitration of all disputes over technological change, and also enables the Labour Relations Board to revive the obligation to bargain collectively in the event of such a dispute. ${ }^{25}$ The latter statute defines technological change very broadly, to include "the in troduction by an employer of a change in his work, undertaking or business." 26 Under this sort of provision, the mere existence of a collective agreement assures at least a temporary, procedural buffer for employees against employer retrenchment decisions.

Some Canadian faculty collective agreements have attempted to go farther, or at least to go in a different direction. The University of Quebec agreements have a long, interesting clause $^{27}$ giving the Academic Council the duty to hear representations from all parties affected by a projected cutback and the duty to make recommendations to the administration, and giving all tenured faculty an apparently absolute right to be reassigned to (or retrained for) another position of some sort within the university. Probationary appointees, in contrast, may be laid off in reverse order of seniority, and have recall rights for twelve months. At St. Mary's, ${ }^{28}$ before any faculty member can be declared redundant there must be "consultation" between union and administration, accompanied by "detailed financial information," and a wide variety of specified alternative measures must be "considered jointly" before any layoffs are made. If the university still decides to proceed with the layoffs, full-time faculty members on other than term appointments are the last to go, and the order of their lay offs must be "based on academic priorities, as agreed upon by the Employer and the Union." Finally, fairly substantial severance pay is provided for any tenured faculty member who loses his job through redundancy. Also of interest in the St. Mary's agreement is a provision that the employer will not sell the university, or amalgamate with any other body, without "prior consultation with the Union, "and that upon any such sale or amalgamation the employer "will use its best efforts" to see that faculty job rights are preserved by the new employer. 29

${ }^{24} \mathrm{RSC} 1970$, c.L-1, (as amended by SC 1972 , c. 18), ss. 149-53.

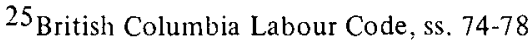

${ }^{26}$ Section 78

${ }^{27}$ In the University of Quebec at Chicoutimi agreement, for example, this clause is art. 12.

28 Agreement between St. Mary's University and St. Mary's University Faculty Union art. 22.

${ }^{29}$ Art. 23 
So much for job security properly so called. Many people are worried about something rather different: that collective agreements will build such a tight link between job security and tenure that only tenured faculty (and therefore, as a rule, older faculty) will survive periods of severed retrenchment. A related fear is that tenure will be seen primarily as a guarantee of a job, and therefore as something acquired automatically after a period of time rather than as a reward for excellence. Whether these fears are justified - or more precisely, whether they will be more justified under collective bargaining than at present will depend on whether the elaborate evaluation procedures that are appearing in faculty collective agreements will succeed in making the tenure-granting process a better test of academic excellence than it now is.

\section{What will happen to "collegial" or "share-authority" bodies under collective bargaining? $29 a$}

Faculty participation in governance at the university-wide level, through representation on senates and other shared-authority bodies, has been acquired with considerable difficulty over a considerable time. In both Canada and the United States, it represents perhaps the most widely accepted means of lessening the degree of control exerted within the university by full-time administrators and by other individuals who are not intimately and continuously involved in research and teaching.

However, the shared-authority concept has not always worked as well as faculty members might have expected. Full-time administrators often have a substantial number of ex officio memberships on shared-authority bodies, and their familiarity with the mechanics of the institution tends to give them even a greater voice than their numbers would indicate. ${ }^{30}$ Elected faculty representatives, even if their initial orientation upon taking office is that of a full-time scholar and teacher, tend not uncommonly to acquire a somewhat more managerial outlook after a certain time. In addition, the sheer size of many shared-authority bodies, necessitated by the presence of administrators, faculty, students, librarians and others, has limited their effectiveness. Still, most faculty members, in my observation, are quite aware of the advantages to themselves and to the university of such bodies, and are most reluctant to do any thing that will seriously undermine their operation.

Accordingly, the parties to faculty collective bargaining in the United States have evolved a variety of approaches designed to regulate the relationship between bargaining machinery and shared-authority bodies and to prevent the former from overwhelming and stultifying the latter. These approaches have recently been canvassed in a very instructive fashion by two members of the Rutgers faculty, who found that almost nowhere did relationships reduce themselves to "the traditional union model in which all faculty input to decision making is channeled entirely through the bargaining agent." 31 The same authors observe that "to date, there is almost no evidence to support a conclusion that collective bargaining has led to a

$29 \mathrm{a}$ The answer to this question is taken from my paper, "Faculty Collective Bargaining and University Governance," presented to the Invitational Seminar on Collective Bargaining in Higher Education in Canada, Banff, Alberta, on January 25, 1975.

${ }^{30}$ This appears to have been the case at St. Mary's. See Fredricksen, "St. Mary's University Faculty Union: A Case Study" unpublished seminar paper, Dalhousie Faculty of Law, 1974.

${ }^{31}$ Begin and Weinberg, "Dispute Resolution in Higher Education", 1974, p. 25 (to be published in proceedings of 1974 annual meeting, Society of Professionals in Dispute Resolution, Chicago). 
significant dismantling of the traditional institution-wide or system-wide governance procedures such as senates or faculty councils." 32

The same observation would seem to be justified in Canada. Collective agreements at the University of Quebec deal in detail with the Academic Council at each constituent campus, and seek to consolidate and clarify the academic governance role sketched out for those Councils by statute. A major aim of collective bargaining in the Alberta colleges is the strengthening of the academic councils in order to give faculty members a greater voice in academic affairs. At St. Mary's University, the governing statute sketches out the powers of the Board of Governors and the Senate in very broad and overlapping terms, and makes the Senate's powers "subject to" those of the Board. ${ }^{33}$ The collective agreement appears at least to have given clear recognition to the Senate's contral role in formulating academic policy, and may even have strengthened the Senate's powers vis-a-vis those of the Board by giving the Senate a precise role in electing the faculty members of the renewal, promotion and tenure review committee ${ }^{34}$ and by providing that major program changes or cutbacks "shall ... require the approval of the Senate to the extent provided for in the St. Mary's University Act."35 In addition, the agreement sets up a Faculty Council for each faculty - a governance organ not mentioned in the statute - and gives it certain academic functions. ${ }^{36}$ At Notre Dame University, the preamble to the 1973 and 1974 collective agreements seems designed to ensure that the "highest academic body in the University", the Academic Committee, as well as the General Faculty Council consisting of all faculty members and academic administrators, will continue to be responsible for at least "the formation and recommendation of educational policy within the University." The Faculty Evaluation Committee, established by the collective agreement for the purpose of carrying out all evaluations involving the careers of faculty members at Notre Dame, is set up on a shared authority basis, with three members elected by the General Faculty Council, two senior academic administrators, and one student. ${ }^{37}$

The effectiveness of shared-authority bodies, and indeed the overall climate of relations within the university, can quite easily be undermined by ill-considered attitudes and practices on the part of the bargaining agent in the administration of the collective agreement. When a first collective agreement has just been signed, disenchanted faculty members may at last see their chance to have something done about their long-standing discontents, and may inundate the grievance procedure with a wave of complaints. When this happens, as at City University of New York and to some extent at Notre Dame University, and when the bargaining agent is unable to do an adequate job of filtering the mass of grievances, a lot of

32 Ibid., p. 17

${ }^{33}$ St. Mary's University Act, Statutes of Nova Scotia 1970, c. 147, ss. 8, 13(2).

${ }^{34}$ Agreement between St. Mary's University and St. Mary's University Faculty Union, 1974, art. 11.40(a).

${ }^{35}$ Art. 22.10. It is not clear whether this provision is intended to preserve the paramountcy of the Board's power to "discontinue" departments, programs and the like under s. 8(1) (a) of that Act.

36 Art. 14 .

${ }^{37}$ Agreement between Notre Dame University and Faculty Association of Notre Dame University, 1974, art. 11. 
faculty and administrative time and energy may have to be expended at the various levels of the grievance process. However, if there is a big pot of simmering grievances, it is unlikely to have been cooked up overnight. It is much more likely that the administration, and perhaps the shared-authority bodies as well, had been unresponsive or ineffectual for some time. If so, the fact that the institution might seem for a while to be run by grievance arbitrators will not necessarily hurt its educational performance in the long run.

\section{Are there any terms which must be included in a collective agreement, and any others which must not?}

Although the parties are generally free, as I have repeatedly said above, to bargain on any matter and to put whatever they want into their collective agreement, that freedom is not absolute. Some Canadian labour relations statutes require that every collective agreement contain a clause designating the union as exclusive bargaining agent, and another clause stating that strikes and lockouts are prohibited during the agreement's lifetime. Such clauses merely reiterate rules laid down elsewhere in the statute, and are of little importance.

Far more significant is the statutory requirement that every collective agreement provide a procedure for the final and binding settlement of grievances - i.e., disputes over the meaning of the agreement or over allegations of noncompliance with its terms. In Ontario, that procedure must be "arbitration." 38 Thus, where the parties had set up an insurance program through their collective agreement but had expressly excluded that program from the scope of the grievance arbitration clause, the Ontario Labour Relations Board held the purported exclusion to be ineffective. The Ontario Court of Appeal, in refusing to quash the Board's decision, held that the "group of sections relating to the contents of collective agreements ... are mandatory in their nature and effect." 39

The statutes of most other provinces do not require that grievances be determinable by arbitration alone, but "by arbitration or otherwise," 40 or "by arbitration or such other method as may be agreed to by the parties." 41 Recently, in Cassiar Asbestos Corp., the Labour Relations Board of British Columbia held that the latter provision entitled a union to demand arbitration of the question whether the collective agreement's requirement of "just cause" for discharge applied to a probationary employee, even though another term of the agreement stated that a probationary employee could "grieve in respect of any matter other than his discharge or seniority." 42 The same section of the British Columbia statute does have the unique additional requirement that every collective agreement contain a provision "governing the dismissal, discipline, or suspension of an employee bound by the agreement." 43 This would provide some sort of basis for distinguishing Cassiar Asbestos

${ }^{38}$ Ontario Labour Relations Act, s. $37(1)$

${ }^{39}$ American Motors (Canada) Ltd. v. UAW Local 1285 and OLRB [1974] 74 CLLC para. 14, 217.

${ }^{40}$ Nova Scotia Trade Union Act, s. $40(1)$.

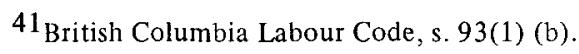

42 [1974] Canadian LRBR 428 (emphasis added).

${ }^{43}$ Section 93(1) (a). 
in other provinces, and other grounds of distinction might also be found. ${ }^{44}$ Still, the decision indicates that it may be legally difficult to exclude from the scope of the grievance procedure such matters as the sufficiency of reasons for withholding tenure from probationary appointees. Canadian law appears to preclude restrictions like that in the City University of New York collective agreements, which make third-party arbitration unavailable for any appointment, tenure or promotion grievance that is found by the arbitrator to involve "academic judgment" rather then mere "procedure." What the parties may be able to do, in Ontario as well as in other provinces, is to give final authority to decide certain types of grievance to a different body than that which arbitrates the general run of grievances - for example, to the university senate or to a special committee, or even (though not in Ontario, because it would not be "arbitration") to some member of the university administration.

What sorts of terms may not be included in a faculty collective agreement? In general, only those terms which violate some statute 45 or which involve the exercise of powers given by the university's governing statute to a body other than the university "management" (i.e., other than the board of governors). For example, the Alberta Universities Act ${ }^{46}$ gives the General Faculties Council of each university the power to "determine standards and policies respecting the admission of persons to the university as students . . "

Labour relations statutes themselves generally impose only a few direct restrictions on what can go into a collective agreement. Union security clauses are commonly an object of such restrictions of a limited sort. In Ontario, for example, a union which has been voluntary recognized rather than certified may not generally have a "closed shop" or "union shop" clause in its agreement until the agreement has been in force for a year. Many other terms of labour relations statutes have an important indirect effect on the content and legal force of collective agreements, but do not directly relate to the bargaining process. An example is the rule that any collective agreement covering a unit of employees precludes a rival union from applying for bargaining rights for that unit except during the last two months of the agreement's term of operation - the so-called "open season."

Everything that I have said about the substantially unlimited scope of bargainable issues is premised upon the fact that Canadian universities, however dependent they are on government for financial support, are in the private sector for purposes of labour relations law. Unlike most American states, no province has yet brought the labour relations in its universities into the public sector, although such a move is being considered in Alberta. Public sector labour relations in most Canadian jurisdictions are governed by separate statutes which place more or less severe limitations on what is bargainable. Those limitations are based on two rather questionable assumptions: first, that it is inconsistent with the sovereignty of the state to allow public servants to pressure the government into yielding some of its management rights; and second, that the government is in an intrinsically weak bargaining position because of its access to the bottomless public purse.

${ }^{44}$ One such ground might be the absence in other provinces of a provision similar to s. $96(1)$ of the B.C. Labour Code, which gives the Labour Relations Board the power to decide the arbitrability of grievances.

${ }^{45}$ The invalidity or unenforceability of such terms is by no means always clear. Weiler, "The Arbitrator, the Collective Agreement and the Law," (1972) 10 Osgoode Hall L. J. 141.

${ }^{46}$ RSA 1970, c. 378, s. 34. 


\section{Will it be legal for faculty unions to strike and picket?}

Under the common law as it had developed up to the Second World War, a trade union probably had the right to strike for the economic advantage of its members. The employer, however, had the corresponding right to fire striking employees for the mere act of going on strike. And the common law provided no means other than the threat of strike by which a union could legally compel an employer to engage in collective bargaining.

Modern Canadian labour relations legislation, enacted since the war, embodies some important tradeoffs. The union's right to strike has been hedged about with important procedural restraints that are designed to induce the parties to do a lot of talking and perhaps a bit of thinking before resorting to a strike (or to the employer's counterpart to the strike - the lockout). Two major procedural requirements must be met before a strike can legally be called. First, the union must acquire statutory bargaining rights through certification or voluntary recognition. Second, the parties must have tried and failed to reach agreement through collective bargaining, and must then have aired their differences in the presence of a government conciliator. Only after the conciliator has decided that the parties are not apt to be conciliated, and after a further one or two-week "cooling-off period" has elapsed, and (in some provinces) after the employees in the bargaining unit have voted to strike in a government-supervised strike ballot and have given the employer 48 hours' further strike notice 47 - only then can the union legally use the strike weapon. And if the collective bargaining process, instead of breaking down, results in a collective agreement, strikes are flatly prohibited during the lifetime of the agreement even if the strike is called to protest a blatant employer violation of the agreement. Only grievance arbitration is available for the redress of such violations.

At least two significant benefits are given to unions and their members in return for these rather legnthy postponements of the right to strike. One such benefit is the right, through the certification process, to have the labour relations board require the employer to bargain collectively. Another is the statutory assertion that employees may not be fired merely because they have gone out on a legal strike. ${ }^{48}$ Now that it has become clear that faculty members are employees within the meaning of labour relations statutes, it is also clear that they are entitled to all the benefits and subject to all the burdens of those statutes.

Such legislation, however, does not disclose the full extent of the legal burdens imposed upon a union which wants to use the strike weapon or engage in picketing or boycotting. If a union calls a strike which is illegal for any of the reasons discussed above, it is quite clear that the courts will grant an injunction against any picketing or boycotting carried on in support of that statute, ${ }^{49}$ even if the picketing or boycotting is perfectly peaceful and

\section{${ }^{47}$ Nova Scotia Trade Union Act, s. 45(3).}

${ }^{48}$ Nova Scotia Trade Union Act, s. 13. An almost identical clause in the Ontario Labour Relations Act - s. 1(2)--is elaborated upon by another provision - s. 64 - to the effect that a legally striking employee is entitled to reinstatement in his job within six months of the beginning of the strike, provided only that the employer has not eliminated the job in the meantime.

${ }^{49}$ Merloni v. Acme Construction Co. Ltd. (1962) 31 DLR (2d) 528 (N.B. Sup. Ct.): In addition to the injunction remedy, the law in some provinces allows the recovery of damages against a union for an illegal strike, either through court action or through arbitration. Ontario Labour Relations Act, s. 84; Gagnon v. Foundation Maritime Ltd. (1961) 28 DLR (2d) 174 (Sup. Ct. of Canada); Jacobson Brothers Ltd. v. Anderson (1962) 35 DLR (2d) 746 (N.S. Sup. Ct.). 
even if it does not involve any untrue statements about the employer. Nothing in the statutes requires this conclusion that the illegality of the strike taints all supporting activity; it is a conclusion which the courts have superimposed upon the statutory regime on the basis of common law tort doctrines. Even if the strike is a legal one, the courts in most provinces will usually enjoin what is called "secondary" picketing - i.e., picketing carried on not at the premises of the employer himself but at the premises of other enterprises with whom the employer does business, such as his suppliers of goods and materials. ${ }^{50}$ Even if the strike is legal and the picketing is "primary" (i.e., directed against the employer's own premises) and therefore permissible in principle, the courts may nonetheless use the injunction to impose strict limits on the number of people who may be on the picket line at any one time. Finally, if there is no strike at all - legal or illegal - but the union decides to set up a picket line to help its organizing campaign or its efforts at the bargaining table, the employer may be able to get an injunction against the picketing. 51

Thus, if a Canadian faculty union does resort to a strike, there are substantial legal restrictions on what it can do in support of the strike. Those restrictions are by no means absolute, and strikes in many other areas of the economy have been successful in spite of them. Still, together with such non-legal factors as the almost certain public hostility that would be incurred by striking faculty members and the lack of a pressing short-term need for their services, the legal obstacles may well have the effect of ensuring that faculty strikes are used only as an absolute last resort.

\section{Will faculty unions be able to discriminate against unpopular members, or to disregard} the interests of individuals in favour of the interests of the group?

Collective bargaining is based on the assumption, which is usually correct, that a group of individuals can more effectively advance their common interests by acting together than by acting individually. Central to a bargaining agent's role is the identification of matters of common interest, their ranking in some order of priority, and their effective advancement at the bargaining table and in the administration of the collective agreement. Canadian labour relations legislation recognizes that bargaining agents need the right to act on behalf of everyone in the bargaining unit, and it confers that right in clear terms.

It is obvious, though, that there are many situations in which the interests of an individual member will clash with those of the group. In such cases, what the law generally treats as a two-party relationship (between the employer and the union) becomes in reality a three-party relationship (between the employer, the union and the individual employee). Our legal system has always had difficulty with three-party relationships, a difficulty exemplified by the gropings of legislatures, courts and labour relations boards for ways to protect individual interests in the collective bargaining process without drastically impairing the union's effectiveness in advancing the collective interest.

${ }^{50}$ See Arthurs, "Labour Law - Secondary Picketing - Per Se Illegality - Public Policy." (1963) 41 Can. Bar Rev. 573. But see also Nedco Ltd. v. Nichols [1973] 3 O.R. 944, at pp. 951-52; Arthurs, "The Dullest Bill: Reflections on the Labour Code of British Columbia," (1974) 9 UBC L Rev. 280, at pp. 301-13.

${ }^{51}$ See Palmer, "The Short, Unhappy Life of the Artistocratic Doctrine" (1960) 13 UTLJ 166, at pp. 186-88. 
Foremost among the indivifual's legal protections is the "duty of fair representation" recently imposed upon bargaining agents by statute or judicial decision. Section 60 of the Ontario Labour Relations Act provides that no bargaining agent shall "act in a manner that is arbitrary, discriminatory or in bad faith in the representation of any of the employees in the unit, whether or not members of the trade union." This duty, which in other provinces is court-created ${ }^{52}$ rather than statute-created, clearly seeks to provide the individual em. ployee with protection at two different stages: first, during the negotiation of a collective agreement, and second, during the processing of grievances once the agreement is in force. However, although quite a large number of complaints under s. 60 have been brought before the Ontario Labour Relations Board, only in a few cases has the Board held the duty of fair representation to have been violated. The main reason is the extreme difficulty of proving the subjective hostility toward the individual complainant which the words of the statute seem to require. A charge that anyone, including a trade union, has acted in an "arbitrary" or "discriminatory" fashion or in "bad faith" is not one that can lightly be proven. In fact, in the two most significant cases in which a substantial remedy in damages has been awarded to an individual against the union for breach of the duty, the Board moved away from the statute's emphasis on subjective ill-will and held that proof of what might be called negligence or incompetence by the union is the processing of an individual's grievance was enough to make out a case for "arbitrary" treatment. ${ }^{53}$ Those cases, I am told, have had a considerable effect on union grievance-handling practices in Ontario.

When what is in question is neither subjective ill-will nor negligence on the part of the union but merely a sharp conflict of interest between the individual and the rest of the bargaining unit, it is still very doubtful whether the duty of fair representation will provide any protection for the individual. If his co plaint is that the union did not press for his particular interests when it presented its demands at the bargaining table, his chances of success are remote unless he can show that the union or its bargaining committee refused to listen to his demands or, having heard them, rejected them out of hand. As long as the union can show that it listened and considered, and that its decision not to press for the complainant's demands was based on its view of the overall interest of the bargaining unit, it is probably homefree. ${ }^{54}$ If the individual's complaint is based not on what the union did or did not ask for at the bargaining table but on the union's refusal to process his grievance under an existing collective agreement because the union had decided that it was impolitic to press the particular grievance at the particular time, his chances of success may be somewhat better. The Ontario Labour Relations Board has recently delivered the most thorough and thoughtful judgment given anywhere in North America on the scope of the duty of fair representation in the grievance-handling situation, ${ }^{54}$ and (unless that judgment turns out to be an aberration) it seems likely that the Board will in appropriate cases allow an individual grievor to carry his own grievance to a specially constituted arbitration tribunal instead of leaving the union with complete power to block access to grievance arbitration. At last, the "institutional" approach

52 Fisher v. Pemberton (1970) 8 DLR (3d) 521 (B.C. Supreme Court).

${ }^{53}$ Stoutley v. Bartenders and Waiters Union [1972] OLRB Rep. (Oct.) 862; Compton v. Woodworkers [1972] OLRB Rep. (Oct.) 916.

${ }^{54}$ Gordon v. Auty Printing Ltd. [1973] OLRB Rep. (Jan.) 36. 
which has understandably but wrongly dominated the law on individual-union relations under Canadian collective bargaining legislation may be slowly giving way to a greater sensitivity to individual rights.

Canadian labour relations statutes generally allow the inclusion of "union security" clauses in collective agreements --i.e., clauses which require an individual, if he is to keep his job, to become a member of the union (a "union shop" or "closed shop" clause) or to pay union dues (an "agency shop" or "Rand formula" clause). The agreements at St. Mary's and Notre Dame both have Rand formula clauses. ${ }^{55}$ Stronger clauses of the union shop or closed shop variety are still virtually nonexistent in North American faculty collective agreements, but could legally be included.

Existing statutory and common law provides an employee with a certain degree of protection against the unfair use of a chosed shop or union shop clause by the union to procure his dismissal. The Nova Scotia Trade Union Act, for example, invalidates any clause which requires an employer to discharge an employee because of his membership in or his support of a rival union. ${ }^{56}$ The Ontario statute has more extensive provisions protecting an employee who is expelled from his union for any of a wider range of reasons deemed by the legislature to be inadequate (e.g., because he "engaged in reasonable dissent within the trade union", or because he was "discriminated against by the trade union is the application of its membership rules.") 57 Even if such statutory protection is inapplicable in a particular case, an employee who is expell. ed from a union in breach of its constitution or without a proper hearing may have a common law right to a court order reinstating him as a member of the union. ${ }^{58}$

The various protections just discussed, even regarded as liberally as possible, fall considerably short of justifying the conclusion that faculty unions may not legally discriminate against unpopular members, and even further short of denying to such unions the right to trade off the interests of individual faculty members in favour of the interests of the entire bargaining unit. Much more important in practice than the legal rules, however, is the degree of awareness within the particular faculty association that the very existence of a university depends on freedom of individual thought and action, and that internal union procedures ought therefore to be designed to protect the right to be unpopular. As for the processing of grievances, the Canadian Association of University Teachers' Guidelines on Collective Bargaining state that a collective agreement should guarantee the individual faculty member's right to take his grievance to arbitration himself, without his local association's consent, "in cases of dismissal for cause." For a second category of grievance, those involving "non-renewal, denial of tenure or refusal of promotion leading to non-renewal," the Guidelines provide that if the local association has the right under the collective agreement to refuse to carry the grievance to arbitration, the grievor can appeal the refusal to the CAUT which can then, if it sees fit, "request"

${ }^{55}$ St. Mary's agreement, art. 3.10; Notre Dame agreement, art. 6(B).

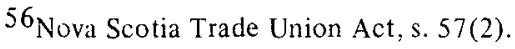

${ }^{57}$ Ontario Labour Relations Act, s. 38(2) and (3). The limitations of such provisions are indicated by McAnally Freightways [1964] CLLC para. 16,011 (OLRB), and Jurak v. Cunningham (1959) 21 DLR (2d) 58 (B.C. Supreme Court).

58 Bimson v. Johnston (1957) 10 DLR (2d) 11 (Ont. High Court); O'Laughlin v. Halifax Longshoremen's Association (1971) 15 DLR (3d) 316 (N.S. Supreme Court). 
the local association to take the matter to arbitration. I suggest that grievance and arbitration clauses should be drawn even more liberally, allowing the grievor himself to take to arbitration any non-renewal grievance or denial of tenure grievance (as well as grievances over dismissal for cause), with the association paying all or most of the costs within specified limits. Unions, including faculty unions, do sometimes make arbitrary or (more often) just plain wrong decisions not to push quite worthy grievances on to arbitration. It may be true that the efficiency of grievance procedures in some industries and even in universities would be impaired if every terminated employee could demand that his grievance be heard by an arbitrator, but the risk is well worth taking.

\section{Could there be faculty collective bargaining at the province-wide level as well as at the individual university level?}

Canadian universities now rely heavily upon provincial governments for financial support. Such support, or at least that portion which goes to meet operating costs, is generally calculated on the basis of an established formula related to student numbers rather than on the basis of annual representations made by the university to the government. This means that no university administration has any substantial control over how much money it will have from year to year. Faculty collective bargaining at the level of the individual university can therefore do relatively little to increase the funds available for faculty salaries and for other purposes deemed necessary by faculty members.

Is there any way in which faculty associations at the various universities in a province can legally compel either the universities or the government to negotiate faculty salaries, or any other issue, on a province-wide basis? The answer is no. If the universities were all agreeable to negotiating salaries or any other matters at the provincial level with a confederation of faculty associations, they could legally do so, and any collective agreement reached through such negotiations would probably be binding. But a union or a confederation of unions cannot use existing labour relations legislation to compel a group of employers to negotiate as a group, unless there is already a collective agreement with that group of employers and the agreement is about to expire. ${ }^{59}$ In some provinces, including Ontario, certification is possible only for a single-employer unit ${ }^{60}$ except in the construction industry. In other provinces, including Nova Scotia, a union or a group of unions may be certified for an otherwise appropriate unit consisting of the employees of more than one employer, but only if every affected employer consents to such certification. ${ }^{61}$

Much more important is the question of true "upper-tier" bargaining between the government on one side and a coalition of universities and faculty associations on the other. Such a system can of course be established by agreement between the government and the parties, or by legislative enactment. Very recently, a joint committee representing the Ontario Confederation of University Faculty Associations and the Ontario university presidents put forward a tentative proposal for province-wide negotiations based in part on the system in

\footnotetext{
${ }^{59}$ Ontario Labour Relations Act, s. 45; Nova Scotia Trade Union Act. s. 32.

${ }^{60}$ Ontario Labour Relations Act. s. 5(1).

${ }^{61}$ Nova Scotia Trade Union Act, s. 24(4).
} 
Britain. ${ }^{62}$ In terms of subject matter, the upper-tier negotiations would be limited to the general area of faculty salaries, and more specifically to average annual increases in salary scales, in the career progress and merit component, and in salary-related fringe benefits. Left for the lower tier ("individual university decision") would be rank floors, policies for the allocation of career progress and merit moneys, the exact amount of each individual's salary, such "equivalents to benefits" as sabbaticals, and "all other salary-related matters" not covered at the upper-tier. ${ }^{63}$ Of the many non-salary issues closely tied up with salary questions, the only one which the proposal discusses at length, treats as fundamental to upper-tier negotiations, and proposes a short-term formula for resolving, is that of faculty numbers, or "entitlement." The difficulty of keeping certain other non-salary matters (principally workload and faculty age mix) off the provincial bargaining table is adverted to but not examined.

As for procedures for the upper-tier negotiations, the proposal suggests the virtual imitation of the British scheme. ${ }^{64}$ Representatives of universities and faculty associations would work out a common position between themselves in Committee A, and would carry that position into Committee B where they would negotiate with the government for its acceptance. In the rather likely event of an impasse in Committee B between the government and the universities side, the chairman of Committee B would in effect act as arbitrator, both sides (including, of course, the government) having bound themselves in advance to abide by the results of the arbitration. The proposal expressly leaves open the question of who would play the important role of chairman of Committee B. One of the most important features of the British system is that the government is represented in Committee B by the education ministry while the chairman of that Committee is chosen by the labour ministry. One government department is in effect interposed as arbitrator between another government department and the universities.

However helpful the OCUFA/Presidents proposal may be in clarifying what is involved in establishing an upper-tier system, it inevitably leaves many questions unanswered. Assuming (and perhaps it is a large assumption) that the Ontario government would agree to the annual arbitration of the major portion of university operating grants, is it realistic to expect that any government-appointed arbitrator (even one appointed by the Ministry of Labour rather than the Ministry of University Affairs) would be independent enough of the government and of the public sentiments of the moment to take real account of the needs of the universities? Were Committee B not given power to arbitrate, some other sanction would have to be available to the university side if the negotiations were not to become mere lobbying. Perhaps the strike would be made available, but in the present climate I doubt it. I aiso doubt that mere open lobbying under such a scheme would give universities and their faculties any greater voice in government financing decisions then they now have in most provinces through such buffers as the Ontario Council on University Affairs and through other channels. As for the bargaining position of the faculty side vis-à-vis the universities in Committee $A$ and that of the university side vis-à-vis the government in Committee B, the lack of a background of effective concen-

62."Progress Report from Ad Hoc OCUFA/Presidents Working Group," Toronto, January 11, 1975

63 Ibid., at p. 2.

${ }^{64}$ Ibid., at p. 3. 
trated action by Ontario university teachers at either the university level or the provincial level does not augur well for the working of any upper-tier procedure in the immediate future.

Whatever the merits of any particular proposal, direct negotiations with the government will certainly have to come before long, in Ontario and elsewhere, if universities are to retain a decent place in the queue for government dollars. However, such negotiations cannot do any thing to improve structures and procedures in those universities where administrators still effectively hold unilateral power on a significant range of matters. In such places universitylevel collective action by faculty members, whether under labour relations legislation or not, is the only means in sight for improving the present distribution of power and for providing some assurance that any settlements made at the upper tier will not be applied within the university in a manner adverse to faculty interests and ultimately to the interests of the university itself. 